\title{
Testicular Cancer pTis TNM Finding v7
}

National Cancer Institute

\section{Source}

National Cancer Institute. Testicular Cancer pT is TNM Finding V7. NCI Thesaurus. Code C89241.

Intratubular germ cell neoplasia (carcinoma in situ). (from AJCC 7th Ed.) 